\title{
International Myositis Assessment and Clinical Studies Group
}

National Cancer Institute

\section{Source}

National Cancer Institute. International Myositis Assessment and Clinical Studies Group. NCl Thesaurus. Code C121335.

A coalition of health care providers and researchers with experience and interest in the myositis syndromes. (adapted from NIEHS website) 